\title{
REALIZATION THE GENETIC POTENTIAL OF MILK PRODUCTIVITY OF HOLSTEIN COWS AT INTENSIVE TECHNOLOGY OF EXPLOITATION
}

\section{Pishchan Stanislav ${ }^{1}$}

DOI: https://doi.org/10.30525/978-9934-571-89-3_106

The reproductive ability to a certain extent characterizes the milk productivity of cows, because the lactation function of cows directly depends on the ability of the animals to reproduce. The duration of lactation is practically determined by the service period, the shorter it is, and the faster the animal is fertilized after calving and shorter the lactation. And, conversely, the longer the period from calving to fertilization, the longer the lactation period $[1 ; 2]$.

The aim of the research was to establish productive and reproductive qualities of pure-breed cows of the Holstein breed of all ages at normal and long-term lactation function. For research were selected animals of the second and third lactation with potentially high milk productivity. All animals were formed in 4 experimental groups: I group $(\mathrm{n}=96)$ - cows of second lactation, service period up to 80 days; II $(n=94)$ group - cows of the third lactation, service period up to 80 days; III group $(n=80)$ - cows of second lactation, service period more than 300 days; IV $(n=62)$ group - cows of the third lactation, service period more than 300 days.

Researches have shown that at industrial technology of exploitation, the level of milk productivity of cows of all groups is high. Thus, in the experimental Holstein cows of I group of the second lactation was received $10749.5 \mathrm{~kg}$ of physical or $10684.0 \mathrm{~kg}$ of $4 \%$ milk, whereas in the well-adapted animals of II group of the third lactation $-10879.4 \mathrm{~kg}$ of physical or $10890.7 \mathrm{~kg} 4 \%$ milk. That is, within the

\footnotetext{
${ }^{1}$ Dnipropetrovsk State Agrarian and Economic University, Ukraine 
305-day lactation, the level of milk productivity of Holstein cows in the second and third lactation is high and practically equal, indicating high genetic potential and optimum level and quality of feeding.

Despite the long lactation function, the experimental animals of III and IV groups according to the productive qualities, brought to the general denominator of comparison, almost exactly corresponded to indicators with normal duration of lactation function. Thus, the level of milk productivity of Holstein cows of III group for the 305-day period of the second lactation is $11260.4 \mathrm{~kg}$ of physical milk, or $4 \%$ milk $-11097.0 \mathrm{~kg}$. Practically the same level of milk productivity is noted in IV group, in which the milk-yield is an average of $11254.1 \mathrm{~kg}$ of physical, or $10930.4 \mathrm{~kg}$ of $4 \%$ milk.

Nevertheless, during the entire lactation period, experimental groups of Holstein cows, with a long lactation period, were characterized by a much higher level of milk-yield. Thus, animals of the III group during the entire second lactation period produced $17213.0 \mathrm{~kg}$ of physical or $16986.0 \mathrm{~kg}$ of $4 \%$ milk. These indicators, of the level milk productivity, higher values of the same animals of the second lactation of I group, respectively, at 36.9 and $36.5 \%$ at a high probability difference of $\mathrm{P}<0.001$.

Cows of IV group of the third lactation period were characterized by a close synthetic activity of milk of the udder of animals of III group, therefore secreted $17382.7 \mathrm{~kg}$ of physical or $16903.5 \mathrm{~kg}$ of $4 \%$ milk. This level of milk productivity exceeds the rate of the same cows of the second group of third lactation, but with a normal productive period, respectively, by 36.4 and $34.6 \%(\mathrm{P}<0.001)$.

It is quite natural that, with the high level of milk productivity, Holstein cows produce a large amount of milk fat and protein. Thus, from animals of the III group during the whole lactation period $440.4 \mathrm{~kg}$ of milk fat and $361.7 \mathrm{~kg}$ of milk protein were obtained. In experimental cows of IV group, these products are respectively 428.6 and $356.5 \mathrm{~kg}$.

The high level of milk productivity was ensured by high-energy feeds, and high metabolic processes in the body of animals. That is, the violation of the energy imbalance in the body, even during prolonged lactation animals was not observed. The high and balanced level of metabolic processes indicated the optimal ratio of milk fat to milk protein products. In experimental Holstein cows, this ratio was at the optimal level, since it is an average of 1.20-1.22 units.

Scientists think that in realizing the genetic potential of milk productivity of cows should also take into account the intensity of reproduction [3-6]. The importance of this issue is substantiated by the fact that in cows immediately after calving, the trophic function of the gland of the internal secretion of the pituitary gland is mainly aimed at increasing the synthesis and secretion of milk in the udder, rather than restoring the cyclic activity of the ovaries. However, despite the hard conditions of the industrial complex and the minimum possibilities for recovery, some highly efficient animals are successfully adapting and displaying high rates of reproductive function. So, in Holstein cows of I group, the insemination index does not exceed 1.2 units, and the reproduction ability is at the level of one. That's why the period between the calving of this research group of cows is almost consistent the duration 
of the year and is on average 357.8 days. In the Holstein cows of the II group, the index of insemination does not exceed 1.4 units, therefore the reproduction ability is at the level of one, since the duration of the service period does not exceed 76.2 days, and the period between calving - 361.2 days. Instead, in the experimental animals of the III group, the index of insemination is on average six units, which fully coincided to the same index of cows of IV group.

According to the industrial technology of milk production, low indicates of reproductive function was also in IV group cows. The duration of the service period in these cows is 419 days, which is 5.24 times longer than normal. It is no coincidence that the period between calving of these Holstein cows is 1.93 times longer than one year, and the reproductive ability does not exceed 0.5 units.

The research has established that if in the experimental cows of groups I and II infertility was completely insignificant and did not exceed 7 and 11.9 days respectively, then the loss of production was also low. So, from each animal of II group in the second lactation period only 0.009 heads of calves were not received. At the same time, from cows of II group losses were only 0.02 heads of calves. Minor infertility indices of these experimental groups determined low milk production losses. Thus, from each Holstein cows of II group was lost $344.4 \mathrm{~kg}$ of milk in the third lactation period, and from each cows of I group of the second lactation - only $195.2 \mathrm{~kg}$.

High levels of reproductive function and low loss of products were the result of the high adaptive properties of these animals to hard conditions of exploitation. So, in the cows of I group, the index of adaptation is positive and makes an average of 0.5 units. A bit lower than the value of adaptation, but also positive, in animals of the II group, in which it makes an average of 0.2 units.

It is well known that the use of gonadoliberins does not always have a positive effect [7]. In addition, the introduction of a luteinizing hormone previously to the endogenous wave before ovulation may result in follicular cysts in animals. That is why, in some high-yielding animals, the reproductive function remains very low, even in cows with a long time of exploitation in the industrial complex. Thus, in the experimental cows of III group in the second lactation the infertility lasted 297.7 days, and in cows of IV (control) group - 339 days. A long period of infertility has caused substantial loss of products. From cows of the III group were not received $7567.2 \mathrm{~kg}$ of milk and one head of calves. Losses of products were still in IV group animals. During the third lactation period, $8202.2 \mathrm{~kg}$ of milk and 1.2 head of calves were lost for each cow of this group.

The low reproductive function of Holstein lactation cows of the second and third lactation determined the indicators of their adaptive plastic organism to intensive exploitation technology. In cows of the III group, the adaptation index is negative and makes -12.3 units on average and in the control group of Holstein cows of the third lactation - -14.2 units. The reproductive ability of cows largely determines the economic efficiency of the enterprise. As noted by M. Z. Basovsky and B. P. Zavertyayev (1975), low fertility indices delay the reproduction rate of the herd and, as a consequence, reduce the intensity of selection of animals by main selection criteria [8]. 
Thus, within the limits of 305-day lactation and milk productivity, listed in $4 \%$ milk, the level of milk-yield of Holstein cows in the second and third lactation is an average of 10684.0-10890.7 kg. For lactation duration more than 600 days the total milk-yield is $17213.0-17382.7 \mathrm{~kg}$, but the milk loss is $7567.2-8202.2 \mathrm{~kg}$, and calves $-1.0-1.2$ heads per each animal.

\section{References:}

1. Vattio M. (1996). Vosproizvodstvo i geneticheskaya selektsii [Reproduction and genetic selection]. Viskonsin. (in Russian)

2. Litvinenko T. V., Dyachenko D. A. (2014) Osobennosti formirovaniya reproduktivnykh kachestv korov golshtinskoy porody $\mathrm{v}$ usloviyakh Lesostepi Ukrainy [Features of the formation of reproductive qualities of Holstein cows in the conditions of the Forest-Steppe of Ukraine]. Izvestiya Orenburgskogo gosudarstvennogo agrarnogo universiteta, no. 1, pp. 100-102. (in Russian)

3. Zasukha T. V., Zubets' M. V., Sirats'kyy Y. Z. (2000). Formuvannya vidtvoryuval'noyi zdatnosti u myasnoyi khudoby [Formation of reproductive ability in beef cattle]. Kyiv: Ahrarna nauka. (in Ukrainian)

4. Shalovylo S. H., Madich A. V., Bets M. Y., Sharan M. M. (1997). Biotekhnolohiya vidtvorennya u skotarstvi [Biotechnology of reproduction in cattle breeding]. Sil's'ki obriyi, no. 10-12, p. 35. (in Ukrainian)

5. Kosenko M., Chukhriy B., Chaykovs'ka O. (2005). Vidtvorennya molochnoho poholiv"ya [Reproduction of dairy cattle]. L'viv: Ukrayins'ki tekhnolohiyi. (in Ukrainian)

6. Smolyaninov B. V., Krotkykh M. O. (2008). Biotekhnolohiya vidtvorennya sil's'kohospodars'kykh tvaryn: navchal'nyy posibnyk [Biotechnology for the reproduction of agricultural animals: a tutorial]. Odesa. (in Ukrainian)

7. Chomaev A. (2007). Ot kazhdoy korovy - po telenku v god [From each cow - one calf a year]. Zhivotnovodstvo Rossii, no. 5, pp. 41-43. (in Russian)

8. Basovskiy N. Z., Zavertyaev B. P. (1975). Selektsiya skota po vosproizvoditel'noy sposobnosti [Selection of cattle by reproductive ability]. Moskva: Rossel'khozizdat. (in Russian) 